\title{
US faces increasing demand for funds to replace ageing equipment
}

\section{Despite moves to boost funding, US biologists are struggling to pay for the instruments they need to remain competitive.}

L ast autumn, Gerald Fischbach, then the new director of the US National Institute of Neurological Disorders and Stroke, sent an unusual letter to the institute's 2,000 extramural scientists, inviting them to apply for one-off $\$ 50,000$ grants for research equipment. The response, he says, was "amazing".

The institute was swamped with 1,800 applications, requesting tools including fluorescence microscopes, sophisticated centrifuges and chromatography equipment. "If we funded every one of them it would have cost $\$ 60$ million," says Fischbach.

Fischbach had just $\$ 10$ million available, but has since added $\$ 5$ million to the programme, allowing him to fund one in four applications." These were not unreasonable requests," he adds. "These are people who have used the same microscope for ten years."

\section{Tremendous problem}

The institute's experience is just one measure of a burgeoning need for up-to-date equipment being felt throughout the biological science community, say university administrators, government officials and scientists.

"Just about every scientist I've ever talked to who is running a big lab is concerned about instrumentation," says Bill Brinkley, outgoing president of the Federation of American Societies for Experimental Biology (FASEB).

"It's a tremendous problem. You can't underestimate it," adds Stanley Opella, a chemist at the University of Pennsylvania, who relies on NMR machines to solve the structure of membrane proteins. There are virtually no sources of federal money for costly instruments, he says.

Warp-speed technological advances have pushed up the price of instruments, while making it vital for laboratories to keep their machinery updated to remain competitive.

Yet this is almost impossible using funds from individual investigator grants administered by the National Institutes of Health (NIH) and the National Science Foundation (NSF). "The NIH is not going to give you $\$ 200,000$ up front in an R01 grant" to help purchase a microscope, says Conley Rieder, a cell biologist who runs an NIH lab for biological microscopy at the Wadsworth Center in Albany, New York.

The NIH spent just over one per cent of its budget - $\$ 150$ million — on equipment in
1998. Just less than half of that was contained in R01 grants, averaging $\$ 9,000$ per grant.

A few programmes administered by the $\mathrm{NIH}$ and the NSF fund equipment that is beyond the scope of individual investigator grants, but scientists say these fail to meet the huge and growing need (see Table 1) and are impractical for buying equipment costing millions of dollars.

The programmes are growing more competitive as innovation draws scientists to demand the latest instruments. The NSF programme that funds shared instruments worth $\$ 40,000$ to $\$ 400,000$ saw applications jump by 30 per cent this year. And the NSF's major research instrumentation programme limits applications for off-the-shelf equipment to two per institution, says Nathaniel Pitts, who is in charge of the programme. Otherwise it would be "unmanageable", he says.

FASEB warned this year of a "broad degradation in the quality and availability of critical state-of-the-art research tools". It recommended that the NIH's \$35 million shared instruments programme should be boosted to $\$ 80$ million.

Senator Tom Harkin (Democrat, Iowa) has introduced a bill that would boost the NIH programme to $\$ 100$ million (see Nature $399,621 ; 1999)$.

In the meantime, many investigators are using obsolete equipment. A 1996 report to the NIH's National Center for Research Resources showed that, in 1993, researchers

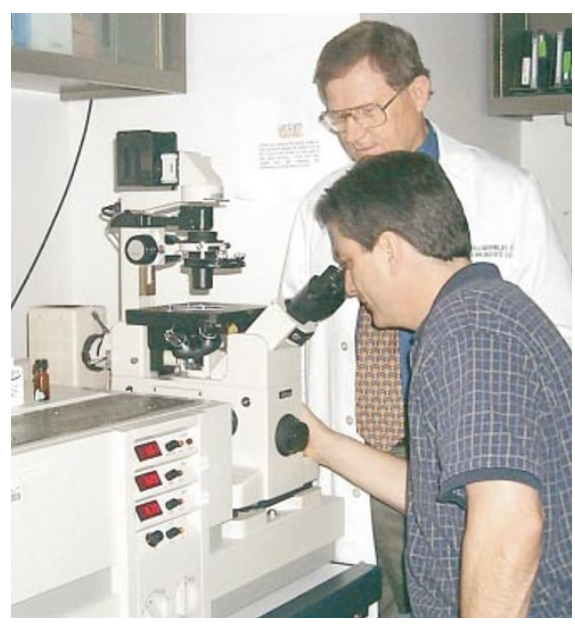

Brinkley (top) with the 1993 microscope for which the service contract has been cancelled.
Table 1 Major US grants available for off-the-shelf biological equipment

National Institutes of Health

Name of programme: Shared Instrumentation Grant Cost of instruments funded: $\quad \$ 100,000-\$ 500,000$ Minimum number of investigators:

Cost of programme: $\$ 35$ million

National Science Foundation

Name of programme: Major Research Instrumentation * Cost of instruments funded: $\quad \$ 143,000-\$ 2$ million Minimum number of investigators: 1 (but more preferred) Cost of programme: $\$ 50$ million (\$10 million for biology)

Name of programme: Multi-user Biological Equipment Cost of instruments funded: $\quad \$ 40,000-\$ 400,000$ Minimum number of investigators:

Cost of programme: $\$ 8.7$ million

*Recipient institution must provide 30 per cent matching funds. Only two applications per institution per year are allowed.

were still using 70 per cent of the equipment from 1982 grants. Judith Vaitukaitis, the centre's director, says that investigators "will use anything they can get their hands on".

The problems with using dated equipment are more than just performance-related. Brinkley, a cell biologist at Baylor College of Medicine in Houston, Texas, says that Molecular Dynamics cancelled the service contract on his department's confocal microscope following the company's acquisition by Amersham Pharmacia Biotech in 1998. The microscope was bought in 1993 with grants from the NIH and NSF.

Because his research on breast cancer is "absolutely dependent" on the microscope, Brinkley may have to fork out tens of thousands of dollars for future repairs.

\section{Alternative sources}

Forced to innovate, investigators such as Opella are piecing together federal funds from disparate sources. The $900-\mathrm{MHz}$ NMR spectrometer that Opella expects to receive this autumn was funded by six grants from three federal agencies.

But some have abandoned the quest for federal funds altogether. A consortium of nine leading New York institutions is financing its own NMR centre at the City University of New York in Manhattan, starting with five spectrometers. Helped by the city's business community, they have financed the project from their own funds and from private foundations and individuals. Meredith Wadman 